\title{
Pengaruh pembatasan pakan terhadap performa ayam pedaging strain yang berbeda
}

\author{
Z. Lantowa, J.J.M.R. Londok*, M.R. Imbar \\ Fakultas Peternakan, Universitas Sam Ratulangi Manado \\ *Korespondensi (corresponding author): jolalondok_unsrat@yahoo.com
}

\begin{abstract}
ABSTRAK
Penelitian ini bertujuan untuk mengukur performa pertumbuhan ayam pedaging dengan strain berbeda melalui pola pembatasan pakan yang dilakukan di awal pertumbuhan (starter). Menggunakan 72 ekor ayam pedaging umur sehari terdiri dari 36 ekor strain Cobb dan 36 ekor strain Lohman yang diperoleh berturut-turut dari PT. Charoen Phokphand dan PT. Japfa Comfeed Indonesia. Menggunakan rancangan acak lengkap (RAL) pola faktorial 2x4x3. Faktor A yaitu perbedaan strain (A1: Lohman; A2: Cobb), dan faktor B yaitu waktu pembatasan pakan (B0: tanpa pembatasan pakan; B1: pembatasan pakan dimulai hari ke 8; B2: pembatasan pakan dimulai hari ke 11; B3: pembatasan pakan dimulai hari ke 14). Pembatasan pakan dilakukan sebanyak 20\%. Variabel yang diukur yaitu konsumsi pakan, pertambahan bobot badan, dan konversi pakan. Analisis ragam menunjukan adanya interaksi nyata $(\mathrm{P}<0,05)$ antara strain berbeda dengan mulainya pembatasan pakan terhadap konsumsi pakan dan pertambahan bobot badan, sedangkan untuk konversi pakan tidak memperlihatkan interaksi ( $\mathrm{P}>0,05)$. Hasil uji Tukey menunjukan bahwa konsumsi pakan pada kombinasi perlakuan strain Lohman dengan waktu pembatasan hari ke 11 A1B2 $(98,95)$ berbeda tidak nyata $(\mathrm{P}>0,05)$ dengan kombinasi A1B0 $(97,52)$, A2B3 $(91,34)$, akan tetapi A2B0 $(95,36)$ berbeda nyata lebih tinggi $(\mathrm{P}<0,05)$ dengan semua kombinasi perlakuan. Pertambahan bobot badan hasil ayam pedaging pada perlakuan A1B2 $(54,63)$ berbeda tidak nyata $(\mathrm{P}>0,05)$ dengan A1B1 $(51,70)$, namun berbeda nyata $(\mathrm{P}<0,05)$ dengan kombinasi perlakuan lainnya. Ayam pedaging strain Lohman dengan pembatasan $20 \%$ dimulai pada hari kesebelas memberikan respon performa terbaik.
\end{abstract}

Kata kunci: Strain, pembatasan pakan, waktu pembatasan.

\begin{abstract}
THE EFFECT OF FEED RESTRICTION ON THE PERFORMANCE OF BROILER WITH DIFFERENT STRAINS. This study aims to measure the growth performance of broilers with different strains through a feed restriction pattern at the beginning of growth (starter). This study used 72 day-old broilers consisting of 36 Cobb strains and 36 Lohman strains selected from each of them. -each 100 heads to get almost the same body weight obtained successively from PT. Charoen Phokphand and PT. Japfa Comfeed Indonesia. The design used was a completely randomized design (CRD) with a $2 \times 4$ factorial pattern with 3 replications. The $\mathrm{A}$ factor is the difference in strains ( $\mathrm{A} 1=$ Lohman, $\mathrm{A} 2=\mathrm{Cobb}$ ), while the $\mathrm{B}$ factor is the time of feed restriction $(\mathrm{B} 0=$ no feed restriction, $\mathrm{B} 1=$ feed restriction starts on day $8, \mathrm{~B} 2=$ Feed restriction starts on day $11, \mathrm{~B} 3=$ Feed restriction begins On day 14 . There were 8 treatment combinations. Feed restriction was carried out as much as 20 percent. The measured variables were feed consumption, body weight gain, and feed conversion. The results
\end{abstract}


of the analysis of variance showed that there was a significant interaction $(\mathrm{P}<0.05)$ between the strains different from the start of the feed restriction on feed consumption and body weight gain, while the feed conversion variable did not show a significant interaction $(\mathrm{P}>0.05)$ .Tukey's test results showed that the feed consumption in the combination of Lohman strain treatment with limitation time of 11 days $(98.95)$ is not significantly different $(\mathrm{P}>0.05)$ with the combination of A1B0 (97.52), A2B3 (91.34), but A2B0 (95.36) is significantly different ( $\mathrm{P}$ $<0.05)$ is higher with all combinations treatment. The results of the analysis of variance showed that there was a significant interaction $(\mathrm{P}<0.05)$ between factor $\mathrm{A}$ and factor $\mathrm{B}$. The results of the Tukey test showed that the treatment of A1B2 (54.63) was not significantly different $(\mathrm{P}>$ 0.05) with A1B1 $(51,70)$, thus with treatment A2B0 (48.13), treatment A1B0 (49.93) with A2B1 (49.13), A2B3 (49.12), A2B0 (48.13) and A2B2 (47.21). Lohman strain broiler and $20 \%$ restriction with restriction time starting on the eleventh day gave the best performance response.

Keywords: Strain, feed restriction, time limitation

\section{PENDAHULUAN}

Ayam Pedaging merupakan salah satu jenis unggas penghasil daging yang potensial, karena masa pemeliharaannya sangat singkat dan pertumbuhannya relatif cepat. Oleh karena itu, ayam pedaging harus memiliki kondisi yang baik terutama pada fase pertumbuhan. Ayam pedaging juga memiliki ciri khas yaitu daging empuk, kulit licin, kenyal, serta tulang rawan dan daging dada yang lunak, ukuran badan besar dengan bentuk dada yang lebar, padat dan berisi, dan efisien terhadap pakan tinggi (Rasyaf, 2007).

Pertumbuhan ayam pedaging dipengaruhi oleh dua faktor yaitu genetik dan lingkungan. Salah satu faktor genetik adalah strain, sedangkan dari faktor lingkungan yang memberikan pengaruh paling besar adalah pakan (Wahju, 1992). Usaha peternakan ayam pedaging saat ini semakin diminati, sehingga strain yang ada dipasaran semakin beragam. Strain yang sering dipelihara oleh peternak ayam pedaging umumnya strain Cobb dan Lohman.

Pakan ayam pedaging harus mengandung zat-zat makanan yang dibutuhkan seperti protein, karbohidrat, mineral, dan vitamin, dimana zat-zat makanan tersebut sangat dibutuhkan oleh ternak. Kebutuhan pakan ayam pedaging pada periode starter untuk protein sebesar 21-24\% sedangkan energi metabolis yang diperlukan sebanyak 2800-3300 kkal/kg (Rasyaf, 2007).

Ayam pedaging termasuk ternak yang mempunyai tingkat keefisienan yang tinggi dalam mengkonversi pakan menjadi daging, namun peternak selalu menghadapi masalah dalam hal harga pakan yang semakin mahal, karena biaya produksi yang dikeluarkan untuk ternak berkisar antar 60 sampai $70 \%$. Oleh karena itu dicari usaha untuk menekan biaya produksi, dalam hal ini yaitu masalah pakan. Salah satu cara yang dapat dilakukan oleh para peternak antara lain dengan membatasi jumlah pakan, karena ayam pedaging cenderung mengkonsumsi pakan melebihi dari kuantitas yang diperlukan sehingga terjadi pemborosan (Sturky, 1976).

Program pembatasan pakan merupakan salah satu upaya yang dapat dilakukan untuk mengurangi dampak konsumsi pakan berlebihan pada sistem pemberian ad libitum. Program pembatasan pakan juga mampu menurunkan konsumsi tanpa menurunkan performa ayam pedaging pada umur panen. Pembatasan pakan pada awal pertumbuhan ayam pedaging merupakan salah satu alternatif untuk menekan permasalahan yang ditimbulkan karena cepatnya pertumbuhan strain ayam pedaging modern sekarang ini. 
Pembatasan pakan dapat menurunkan masalah metabolik yang menyebabkan kematian mendadak serta gangguan kaki (Butzen et al., 2013). Londok et al. (2012) telah melakukan penelitian tentang pengaruh pembatasan pakan terhadap konversi pakan ayam pedaging, hasil penelitian menujukan bahwa pembatasan pakan sampai 20\% memberikan konversi pakan terbaik. Strain sangat berpengaruh terhadap pertumbuhan ayam pedaging. Menurut Lacy dan Vest (2000), salah satu faktor utama yang mempengaruhi pertambahan bobot badan dan konversi pakan adalah genetik, ventilasi, sanitasi dan juga kualitas pakan.

Penelitian dilakukan dengan tujuan untuk mengukur performa pertumbuhan pokphand dan PT. Japfa Comfeed Indonesia.

Kandang yang digunakan saat pertama ayam umur sehari (DOC) tiba yaitu kandang brooder dengan ukuran $200 \times 100$ $\times 40 \mathrm{~cm}^{3}$ dilengkapi dengan lampu pijar sebanyak 2 buah masing-masing 100 watt, dan lantai kandang brooder terbuat dari kawat ram dan dilapisi kertas koran bekas. Kandang yang digunakan saat perlakuan pembatasan pakan ayam pedaging, yaitu kandang sistem baterei sebanyak 8 unit,dimana tiap-tiap unit dibagi menjadi 3 petak, dan dialas dengan koran, serta dilengkapi tempat pakan dan tempat minum pada setiap unit kandang. Perlengkapan kandang lainnya yaitu kertas koran, seperangkat peralatan lampu, timbangan digital berkapasitas 2000 gram, ember, gayung, thermometer, dan label.

\begin{tabular}{llr}
\multicolumn{2}{c}{ Rancangan percobaan yang } \\
digunakan pada penelitian ini \\
menggunakan Rancangan Acak Lengkap
\end{tabular} (RAL) pola faktorial 2x4 dengan 3 ulangan. Faktor $\mathrm{A}=$ strain berbeda $(\mathrm{A} 1=$ Lohman, $\mathrm{A} 2=\mathrm{Cobb})$. Faktor $\mathrm{B}=$ waktu mulainya pembatasan pakan $(\mathrm{B} 0=$ tanpa pembatasan, $\mathrm{B} 1=$ pembatasan pakan dimulai pada hari ke $8, \mathrm{~B} 2=$ pembatasan dimulai pada hari ke 11 dan B3 = pembatasan dimulai pada hari ke 14). Pembatasan pakan dilakukan sebanyak 20 persen untuk setiap perlakuan. ayam pedaging dengan strain yang berbeda melalui pola pembatasan pakan yang dilakukan pada awal pertumbuhan(starter).

\section{MATERI DAN METODE PENELITIAN}

Penelitian ini dilaksanakan dikandang percobaan ternak unggas Fakultas Peternakan Universitas Sam Ratulangi Manado. Penelitian di mulai tanggal 11 Mei sampai dengan 15 Juni 2018. Jumlah ternak yang digunakan yaitu 72 ekor ayam pedaging umur sehari terdiri dari 36 ekor strain Cobb dan 36 ekor strain Lohman yang dipilih dari masing-masing 100 ekor untuk mendapatkan bobot badan yang hampir sama, dari PT. Charoen

Terdapat 8 kombinasi perlakuan yaitu 1). A1B0 = Ayam pedaging strain Lohman tanpa pembatasan pakan, 2). A1B1 = Ayam pedaging strain Lohman dengan pembatasan mulai hari ke 8, 3). A1B2 = Ayam pedaging strain Lohman dengan pembatasan pakan mulai hari ke 11, 4). A1B3 = Ayam pedaging strain Lohman dengan pembatasan pakan mulai hari ke 14, 5). $\mathrm{A} 2 \mathrm{~B} 0=$ Ayam pedaging strain $\mathrm{Cobb}$ tanpa pembatasan pakan, 6). A2B1 = Ayam pedaging strain Cobb dengan pembatasan pakan mulai hari ke 8, 7). A2B2 = Ayam pedaging strain Cobb dengan pembatasan mulai hari ke 11, 8). A2B3 = Ayam pedaging strain $\mathrm{Cobb}$ dengan pembatasan pakan mulai ke 14. Uji Tukey dilakukan untuk menguji pengaruh kombinasi perlakuan yang berbeda nyata.

Pakan yang digunakan untuk ayam pedaging strain Cobb fase starter adalah pakan komersial CP 11 dan untuk finisher menggunakan $\mathrm{CP}$ 12. Untuk ayam pedaging strain Lohman pada fase starter dan finisher menggunakan pakan komersial BR 21-E. Berikut komposisi bahan pakan dan kandungan zat-zat makanan yang digunakan dalam penelitian ini dapat dilihat pada Tabel 1.

\section{Persiapan}

Kandang serta lingkungan sekitar dibersihkan lebih dahulu. Tempat pakan 
Tabel 1. Komposisi Zat-Zat Makanan dan Energi Pakan Perlakuan

\begin{tabular}{llll}
\hline Zat makanan dan energi metabolis & CP 11* & BR 21-E** & CP 12* \\
\hline Bahan kering (\%) & 87 & 88 & 87 \\
Protein (\%) & 21 & 22 & 20 \\
Lemak kasar (\%) & 5 & 6 & 5 \\
Serat kasar (\%) & 5 & 5 & 5 \\
Kalsium (\%) & 0,9 & 1,56 & 0,9 \\
Phosphor (\%) & 0,6 & 0,56 & 0,6 \\
Energi Metabolis (kkal/kg) & 2961 & 2900 & 3180 \\
\hline
\end{tabular}

Sumber: * PT. Charoen Pokphand. ** PT. Japfa Comfeed Indonesia

dan minum dicuci dengan menggunakan sabun deterjen.Selanjutnya kandang yang telah dibersikan, dilakukan pengapuran, kemudian disemprot dengan menggunakan desinfektan. Setelah kandang dan peralatan sudah bersih, dilanjutkan dengan penataan kandang, tempat makan dan minum diletakan secara teratur dimasing masing unit kandang serta dipasang lampu pijar 100 watt sebagai sumber pemanas.

\section{Pemeliharaan}

Setelah ayam pedaging DOC tiba di kandang penelitian, ditimbang satu persatu dan diberi label pada kakinya kemudian di masukkan ke dalam kandang brooder, dan memberikan larutan air gula yang bertujuan untuk menghilangkan stress dan menggantikan energi selama pengiriman. Kemudian memberikan pakan masingmasing dalam bentuk crumbel baik strain Cobb maupun Lohman. Ayam diberi vaksinasi untuk mencegah penyakit sebanyak 2 kali yaitu New Castle Diseases (ND) pada umur 1 hari melalui tetes mata dan gumboro pada umur 2 minggu. Setelah berumur satu minggu ternak dipindahkan ke dalam kandang sistem baterei yang sudah disiapkan masing-masing 3 ekor dalam tiap unit, dan memberikan pakan sesuai perlakuan. Data konsumsi dilakukan setiap hari dengan menimbang pakan yang akandiberikan dan sisa pakan setiap harinya. Untuk melihat pertambahan bobot badan dilakukan penimbangan ayam dalam setiap minggu, pengambilan data dilakukan selama 35 hari.

3. Pengambilan data

Data konsumsi pakan diperoleh dengan penimbangan pakan yang diberikan dan pakan sisa. Data pertambahan bobot badan diperoleh dengan menimbang bobot badan ayam setiap minggu.

Variabel penelitian yang diukur:

1. Konsumsi pakan (gram) diperoleh dari selisih antara jumlah pakan yang diberikan dengan sisanya setiap hari.

2. Pertambahan bobot badan (gram) diperoleh dari selisih penimbangan bobot badan akhir dengan bobot badan awal.

3. Konversi pakan yaitu perbandingan antara konsumsi pakan rata-rata ekor-1 hari-1 dengan pertambahan bobot badan rata-rata ekor-1 hari-1 selama periode penelitian.

\section{HASIL DAN PEMBAHASAN}

\section{Pengaruh perlakuan terhadap konsumsi pakan}

Rataan konsumsi pakan selama penelitian dapat dilihat pada Tabel 2. Pada Tabel tersebut terlihat nilai rataan konsumsi pakan berkisar antara 91,34 $\pm 0,00$ sampai 98,95 \pm 0,58 gram ekor ${ }^{-1}$ hari $^{-1}$. Rataan konsumsi pakan tertinggi diperoleh pada ayam strain Lohman dengan pembatasan pakan dimulai pada hari kesebelas (A1B2) dan konsumsi terendah pada ayam strain 
Cobb dengan pembatasan pakan dimulai pada hari kesebelas (A2B2). Nilai konsumsi pakan dalam penelitian ini masih lebih tinggi dibandingkan dengan penelitian dari Muharlien et al. (2010) yaitu berkisar antara 78,62 - 83,62 gram ekor ${ }^{-1}$ hari $^{-1}$. Dalam penelitian ini pembatasan pakan pada hari ke 14 strain cobb, tidak jauh berbeda dengan penelitian Omosebi et al. (2014) yaitu konsumsi pakan 93,81 gram ekor ${ }^{-1}$ hari $^{-1}$, pertambahan bobot badan 40,79 gram ekor $^{-1}$ hari $^{-1}$ dan nilai konversi yaitu 2,3 gram ekor ${ }^{-1}$ hari ${ }^{-1}$, akan tetapi penelitiannya selama 42 hari. Hasil analisis ragam menunjukkan bahwa terdapat interaksi nyata $(\mathrm{P}<0,05)$ antara ayam pedaging strain yang berbeda dan pembatasan pakan terhadap konsumsi pakan. Uji Tukey menunjukkan bahwa konsumsi pakan ayam pedagingstrain Lohman dengan pembatasan pakan mulai pada hari ke sebelas (A1B2) berbeda tidak nyata $(\mathrm{P}>0,05)$ dengan kombinasi ayam strain Lohman tanpa pembatasan (A1B0), demikian halnya dengan perlakuan antara kombinasi ayam pedaging strain Lohman dengan pembatasan pakan mulai pada hari ke empat belas (A1B3) dan kombinasi strain lohman dengan pembatasan pakan mulai pada hari ke delapan (A1B1), kombinasi perlakuan strain Lohman tanpa pembatasan (A1B0), kombinasi strain Cobb dengan pembatasan mulai pada hari ke delapan (A2B1) dan kombinasi strain Cobb dengan pembatasan pakan mulai pada hari ke sebelas, antara kombinasi strain Cobb dengan pembatasan pakan mulai pada hari ke sebelas (A2B2) dan kombinasi strain Cobb dengan pembatasan pakan mulai pada hari ke empat belas (A2B3) terhadap konsumsi pakan. Akan tetapi kombinasi ayam pedaging strain Cobb tanpa pembatasan (A2B0) berbeda nyata $(\mathrm{P}<0,05)$ lebih tinggi dibandingkan dengan semua kombinasi perlakuan lainnya. Hasil ini menunjukkan bahwa kombinasi perlakuan ayam pedaging strain Lohman dengan pembatasan pakan yang dimulai pada hari kesebelas (A1B2) memberikan respon yang lebih baik terhadap konsumsi pakan. Faktor-faktor yang mempengaruhi konsumsi pakan yaitu kandungan nutrisi, bobot badan, galur, aktivitas ternak, manajemen pemberian pakan, kandungan energi dalam pakan dan suhu lingkungan (Anggitasari et al., 2016). Tingginya konsumsi pakan pada perlakuan kombinasi ayam pedaging strain Lohman dengan pembatasan pakan mulai pada hari kesebelas menunjukkan bahwa konsumsi ayam pedaging strain Lohman lebih baik dibandingkan dengan strain Cobb setelah diberi pembatasan pakan. Hasil ini sependapat dengan Kurtini et al. (2011) yang menyatakan bahwa pertumbuhan ayam pedaging dipengaruhi oleh dua faktor yaitu genetik 30\% dan lingkungan $70 \%$, salah satu faktor genetik yang mempengaruhi adalah strain dan faktor lingkungan yang mempengaruhi adalah pakan. Ayam pedaging strain Lohman memiliki kelebihanyaitu memiliki nafsu makan yang cukup baik dan ini menunjang pertumbuhan yang baik, sehingga pencapaian bobot badan yang tinggi akan didapatkan dalam waktu singkat. Selain strain, konsumsi pakan dalam penelitian ini juga dipengaruhi oleh pembatasan pakan, dimana terjadi sebuah keadaan pada tubuh ternak yang disebut dengan compensatory growth atau pertumbuhan kompensasi, yaitu kemampuan tumbuh ternak lebih cepat dari pertumbuhan normal setelah mengalami hambatan pertumbuhan akibat terbatasnya pakan. Pembatasan pakan 20 persen lebih efisien dibandingkan dengan tanpa pembatasan dalam mengkonversi pakan menjadi daging (Mendes et al., 2007). Hal ini juga ditunjang oleh David dan Subalini (2015), yang menyatakan bahwa pertumbuhan kompensasi dipengaruhi oleh pembatasan pakan. Pembatasan pakan pada periode starter lebih menguntungkan untuk meningkatkan efisiensi pakan dalam menurunkan biaya pemeliharaan (Tolkamp et al., 2005). 
Tabel 2. Rataan Konsumsi Pakan, Pertambahan Bobot Badan dan Konversi Pakan Ayam Pedaging Kombinasi Strain berbeda dengan Mulainya Pembatasan Pakan pada Fase Starter selama Penelitian (1-35 Hari).

\begin{tabular}{|c|c|c|c|c|c|c|}
\hline \multirow[t]{2}{*}{ Variabel } & \multirow{2}{*}{ Strain } & \multicolumn{4}{|c|}{ Pembatasan Pakan } & \multirow[t]{2}{*}{ Rataan } \\
\hline & & B0 & B1 & B2 & B3 & \\
\hline \multirow{3}{*}{$\begin{array}{l}\text { Konsumsi } \\
\text { Pakan (g) }\end{array}$} & $\mathrm{A} 1$ & $\begin{array}{c}97,52 \pm \\
1,06^{\mathrm{ab}} \\
\end{array}$ & $\begin{array}{c}97,12 \pm \\
1,81^{\mathrm{b}} \\
\end{array}$ & $\begin{array}{c}98,95 \pm \\
0,58^{\mathrm{a}} \\
\end{array}$ & $\begin{array}{c}97,05 \pm \\
1,32^{\mathrm{b}} \\
\end{array}$ & $\begin{array}{c}97,66 \pm \\
0,67 \\
\end{array}$ \\
\hline & $\mathrm{A} 2$ & $\begin{array}{c}95,36 \pm \\
0,00^{\mathrm{c}}\end{array}$ & $\begin{array}{c}93,15 \pm \\
0,00^{\mathrm{d}}\end{array}$ & $\begin{array}{c}92,02 \pm \\
0,00^{\text {de }}\end{array}$ & $\begin{array}{c}91,34 \pm \\
0,00^{\mathrm{e}} \\
\end{array}$ & $\begin{array}{c}92,97 \pm \\
0,00\end{array}$ \\
\hline & Rataan & $\begin{array}{c}94,44 \pm \\
1,53\end{array}$ & $\begin{array}{c}95,13 \pm \\
2,80\end{array}$ & $\begin{array}{c}95,48 \pm \\
4,90\end{array}$ & $\begin{array}{c}94,19 \pm \\
4,03\end{array}$ & $\begin{array}{c}95,31 \pm \\
3,32\end{array}$ \\
\hline \multirow{3}{*}{$\begin{array}{c}\text { Pertambahan } \\
\text { Bobot } \\
\text { Badan }(\mathrm{g})\end{array}$} & A1 & $\begin{array}{c}49,93 \pm \\
1,64^{\text {bcd }}\end{array}$ & $\begin{array}{c}51,70 \pm \\
2,77^{\mathrm{ab}}\end{array}$ & $\begin{array}{c}54,63 \pm \\
1,20^{\mathrm{a}}\end{array}$ & $\begin{array}{c}50,73 \pm \\
2,03^{\mathrm{bc}}\end{array}$ & $\begin{array}{c}51,73 \pm \\
1,91\end{array}$ \\
\hline & $\mathrm{A} 2$ & $\begin{array}{c}48,13 \pm \\
1,66^{\text {cd }} \\
\end{array}$ & $\begin{array}{l}49,13 \pm \\
1,61^{\text {bcd }} \\
\end{array}$ & $\begin{array}{c}47,21 \pm \\
1,24^{\mathrm{d}} \\
\end{array}$ & $\begin{array}{c}49,12 \pm \\
1,73^{\text {bcd }} \\
\end{array}$ & $\begin{array}{c}48,40 \pm \\
1,56\end{array}$ \\
\hline & Rataan & $\begin{array}{c}49,03 \pm \\
1,27 \\
\end{array}$ & $\begin{array}{c}50,42 \pm \\
1,82 \\
\end{array}$ & $\begin{array}{c}50,92 \pm \\
5,24 \\
\end{array}$ & $\begin{array}{c}49,93 \pm \\
1,14 \\
\end{array}$ & $\begin{array}{c}50,08 \pm \\
2,37 \\
\end{array}$ \\
\hline \multirow{3}{*}{$\begin{array}{l}\text { Konversi } \\
\text { Pakan }\end{array}$} & $\mathrm{A} 1$ & $\begin{array}{c}1,95 \pm \\
0,06\end{array}$ & $\begin{array}{c}1,88 \pm \\
0,13 \\
\end{array}$ & $\begin{array}{c}1,81 \pm \\
0,03\end{array}$ & $\begin{array}{c}1,91 \pm \\
0,06\end{array}$ & $\begin{array}{c}1,89 \pm \\
0,06\end{array}$ \\
\hline & $\mathrm{A} 2$ & $\begin{array}{c}1,98 \pm \\
0,07 \\
\end{array}$ & $\begin{array}{c}1,90 \pm \\
0,06\end{array}$ & $\begin{array}{c}1,95 \pm \\
0,05\end{array}$ & $\begin{array}{c}1,86 \pm \\
0,07 \\
\end{array}$ & $\begin{array}{c}1,92 \pm \\
0,05 \\
\end{array}$ \\
\hline & Ratan & $\begin{array}{c}1,97 \pm \\
0,02\end{array}$ & $\begin{array}{c}1,89 \pm \\
0,01 \\
\end{array}$ & $\begin{array}{c}1,88 \pm \\
0,10 \\
\end{array}$ & $\begin{array}{c}1,89 \pm \\
0,04\end{array}$ & $1,91 \pm .$. \\
\hline
\end{tabular}

Keterangan: A1: Strain Lohman, A2: Strain Cobb, B0: Tanpa Pembatsan Pakan, B1: Pembatsan pakan 20\% dimulai Hari Ke 8, B2: Pembatasan pakan 20\% dimulai Hari Ke 11, B3: Pembatasan Paan 20\% dimulai Hari Ke 14.

Superskrip berbeda menunjukkan perbedaan yang nyata $(\mathrm{P}<0,05)$.

\section{Pengaruh perlakuan terhadap pertambahan bobot badan}

Rataan pertambahan bobot badan ayam pedaging selama penelitian dapat dilihat pada Tabel 2. Pada Tabel tersebut, nilai rataan pertambahan bobot badan berkisar antara 47,21 $\pm 1,24$ sampai 54,63 \pm 1,20 gram ekor ${ }^{-1}$ hari $^{-1}$. Rataan pertambahan bobot badan tertinggi diperoleh pada strain Lohman dengan pembatasan 20 persen pada hari ke 11 (A1B2) yaitu 54,63 g dan terendah terdapat pada Strain Cobb dengan pembatasan pakan mulai hari ke 11 (A2B2) yaitu 47,21 g Nilai pertambahan bobot badan ini lebih rendah dibandingkan dengan penelitian dari Idayat et al. (2012) yaitu berkisar antara 82,61 - 85,78 gram ekor $^{-1}$ hari $^{-1}$ dan standar Japfa Comfeed Indonesia (2012) yaitu 67,14 gram $^{-1}$ ekor $^{-1}$ hari $^{-1}$.
Hasil analisis ragam, menunjukkan bahwa terdapat interaksi nyata $(\mathrm{P}<0,05)$ antara perlakuan kombinasi ayam pedaging strain yang berbeda dan pembatasan pakan dengan waktu pembatasan. Hasil uji Tukey, menunjukkan bahwa perlakuan kombinasi ayam pedaging Strain Lohman dengan pembatasan pakan dimulai hari ke sebelas (A1B2) tidak berbeda nyata $(\mathrm{P}>0,05)$ dengan kombinasi ayam pedaging strain Lohman dengan pembatasan pakan mulai pada hari kedelapan (A1B1), demikian pula dengan perlakuan kombinasi ayam pedaging strain Lohman dengan pembatasan pakan mulai pada hari kedelapan (A1B1) dengan kombinasi ayam pedaging strain Lohman dengan pembatasan mulai pada hari keempatbelas (A1B3), kombinasi ayam pedaging strain Lohman tanpa pembatasan (A1B0), kombinasi ayam pedaging strain $\mathrm{Cobb}$ 
dengan pembatasan pakan mulai pada hari kedelapan (A2B1) dan kombinasi strain Cobb dengan pembatasan pakan mulai hari keempatbelas (A2B3) tidak berbeda nyata $(\mathrm{P}>0,05)$. Perlakuan kombinasi ayam pedaging strain Lohman dengan pembatasan mulai pada hari keempatbelas (A1B3), dengan kombinasi ayam pedaging strain Lohman tanpa pembatasan (A1B0), kombinasi ayam pedaging strain Cobb dengan pembatasan pakan mulai pada hari kedelapan (A2B1), kombinasi ayam pedaging strain Cobb dengan waktu pembatasan pakan mulai pada hari keempatbelas (A2B3) dan kombinasi ayam pedaging strain $\mathrm{Cobb}$ tanpa pembatasan (A2B0) tidak berbeda nyata $(\mathrm{P}>0,05)$. Perlakuan kombinasi ayam pedaging strain Lohman tanpa pembatasan (A1B0), dengan kombinasi ayam pedaging strain Cobb dengan waktu pembatasan dimulai pada hari kedelapan (A2B3), kombinasi ayam pedaging strain Cobb dengan pembatasan pakan mulai pada hari keempatbelas A2B3), kombinasi ayam pedaging strain Cobb tanpa pembatasan (A2B0) dan kombinasi ayam pedaging strain Cobb dengan pembatasan pakan mulai pada hari kesebelas tidak berbeda nyata $(\mathrm{P}>0,05)$.

Hasil ini menunjukkan bahwa pertambahan bobot badan pada ayam pedaging strain Lohman dengan pembatasan pakan mulai pada hari kesebelas dan hari kedelapan memberikan respon yang lebih baik. Kondisi ini sama dengan pendapat Tilman et al. (1991), menyatakan bahwa pertambahan bobot badan berhubungan dengan konsumsi pakan yaitu semakin tinggi konsumsi pakan maka bobot badannya akan semakin besar, sebaliknya semakin rendah konsumsi pakan maka bobot badannya semakin kecil. Hal ini menunjukkan bahwa pertambahan bobot badan sejalan dengan jumlah konsumsi pakan dalam penelitian ini. Faktor-faktor yang mempengaruhi pertambahan bobot badan ayam pedaging adalah perbedaan jenis kelamin, konsumsi pakan, lingkungan, bibit dan kualitas pakan (Qurniawan, 2016). Menurut Fadilah
(2005), salah satu factor yang mempengaruhi besar kecilnya pertambahan bobot badan ayam pedaging adalah terpenuhinya kebutuhan zat makanan ayam pedaging, maka konsumsi pakan seharusnya memiliki korelasi positif dengan pertambahan bobot badan. Selain konsumsi pakan, pembatasan pakan juga mempengaruhi pertambahan bobot badan ternak. Hal ini ditunjang oleh Utami, 2011 yang menyatakan bahwa pembatasan pada umur 5 sampai 8 minggu, ayam pedaging yang mendapat pembatasan pakan ternyata tidak memberikan respon yang baik, karena kesempatan ayam pedaging untuk mendapatkan laju pertumbuhan yang cepat menjadi sangat berkurang. Akibatnya walaupun efisiensi pakan lebih baik dan kadarlemaknya rendah, namun berat badannya tidak mencapai ukuran normal, oleh karena itu disarankan untuk pembatasanpakan di awal pertumbuhannya yaitu umur 3-11 hari.

\section{Pengaruh Perlakuan terhadap Konversi Pakan}

Rataan konversi pakan ayam pedaging selama penelitian dapat dilihat pada Tabel 2. Pada Tabel tersebut terlihat nilai rataan konversi pakan berkisar antara $1,81 \pm 0,03-1,98 \pm 0,07$. Rataan tertinggi diperoleh pada kombinasi perlakuan strain Cobb tanpa pembatasan pakan (A2B0) dan terendah pada kombinasi perlakuan pada strain Lohman dengan pembatasan pakan mulai hari ke 11 (A1B2). Nilai konversi ini lebih tinggi dibandingkan dengan penelitian dari Idayat et al. (2012) yaitu berkisar antara 1,54 - 1,59. Menurut Santoso (2002) bahwa konversi pakan pada ayam pedaging selama 5 minggu sebesar 1,6. Namun masih dalam batas yang dianjurkan Lesson dan Summer (2000) yaitu pemeliharaan ayam pedaging masih dikatakan efisien bila nilai konversi pakan dibawah angka dua.

Hasil analisis ragam menunjukkan bahwa perlakuan berpengaruh tidak nyata $(\mathrm{P}>0,00)$ terhadap ayam pedaging strain yang berbeda dan waktu pembatasan pakan 
terhadap konversi pakan. Menurut Irawan (1996), konversi pakan dipengaruhi oleh beberapa faktor antara lain jenis ternak, keadaan kandang (lingkungan), jenis kelamin dan umur. Keadaaan ternak dalam penelitian ini sama, sehingga konversi pakannya pun tidak berbeda. Ayam pedaging dengan umur yang relatif sama memiliki kemampuan yang sama pula, sehingga kemampuan mencerna tidak berbeda. Konversi pakan merupakan salah satu tolak ukur untuk menilai tingkat efisiensi penggunaan pakan. Jika nilai konversi pakan yang ditunjukkan tinggi, maka efisiensi penggunaan pakan rendah. Sebaliknya jika nilai konversi pakan rendah, maka efisiensi penggunaan pakan tinggi atau baik. Faktor yang mempengaruhi konversi pakan adalah konsumsi pakan dan pertambahan bobot badan. Dalam penelitian ini nilai pembatasan pakan, pada periode starter tidak mempengaruhi konversi pakan

\section{KESIMPULAN}

Ayam pedaging strain Lohman dengan pembatasan $20 \%$ dimulai pada hari kesebelas memberikan respon performa terbaik.

\section{DAFTAR PUSTAKA}

Anggitasari, S., O. Sofjan dan I.H. Djunaidi. 2016. Pengaruh jenis pakan komersial terhadap kinerja produksi kuantitatif dan kualitatif ayam pedaging. Buletin Peternakan 40(3): 187-196.

Butzen, F.M., A.M.L. Ribeiro, M.M. Vieira, A.M. Kessler, J.C. Dadalt dan M.P. Della. 2013. Early feed restriction in broilers, I-performance, body fraction weight, and meat quality. J.Appl. Poult. Res. 22:251259.

David, L. S. dan E. Subalini. 2015. Effects of feed restriction on the growth performance, organ size and carcass characteristics of broiler chickens.
Sch. J. Agric. Vet. Sci.2 (2A):108111.

Fadilah. 2005. Panduan Mengelola Peternakan Ayam Broiler Komersial. Agromedia Pustaka. Jakarta

Idayat, A., U. Atmomarsono dan W. Sarengat. 2012. Pengaruh berbagai frekuensi pemberian pakan pada pembatasan pakan terhadap performans ayam broiler. Animal Agriculture Journal 1(1): 379-388.

Irawan, A. 1996. Ayam-ayam Pedaging Unggul. CV. Aneka Ilmu. Solo.Japfa Comfeed Indonesia. 2012. Performa Broiler MB 202. PT. JCI, Jakarta

Japfa Comfeed Indonesia. 2012. Performa Broiler MB 202. PT. JCI, Jakarta.

Kurtini, T., K. Nova. dan D. Septinova. 2011. Produksi Ternak Unggas. Universitas Lampung. Bandar Lampung

Lacy, M. dan L.R. Vest. 2004. Meningkatkan konversi pakan pada ayam pedaging: Panduan bagi pembudidaya. Diambil 06 maret 2018 .

http://www.ces.uga.edu/pubed/c:793 -W.html.

Lesson, S. and J. D. Summer. 2000. Production and carcass characteristic of the broiler. Poult.Sci. 59: 786-798.

Londok, J.J.M.R., B. Tulung, Y.H.S. Kowel dan J.E.G. Rompis. 2012. Effect of feed restriction on feed efficiency, carcass quality and digestive organs charactheristic of broiler. Proceeding. Internatioanal Seminar "feed safety for healthy food". AINI and Faculty of Animal Husbandry. Universitas Padjajaran. Jatinagor.

Nuraga, Y. A., F. N. Sompie, Y. H. S. Kowel dan M. N. Regar. 2018. Pengaruh penggantian sebagian jagung dengan silase kulit pisang kepok (musa paradisiaca formatypica) dalam ransum terhadap performans ayam broiler. Zootec 38(1): $244-252$ 
Manalip, O. M., M. Najoan, M. R. Imbar dan Y. H. S. Kowel. 2018. Penggatian sebagian jagung dengan tepung batang pisang goroho (Musa acuminate $s p$ ) dalam ransum terhadap performans broiler. Zootec 38(2): $296-305$

Mendes, M.E.H.M.E.T., E.C.M.E.L Dincer dan E. Arslan. 2007. Profile analysis and growth curve for body mass index of broiler chickens reared under different feed restrictions in early age. Arch. Animal Breeding 50(4): 403-411

Omosebi, D.J., O.A. Adeyemi, M.O. Sogunle, O.M.O. Idowo dan C.P. Njoku. 2014. Effects of duration and level of feed restriction on performance and meat quality of broiler chickens. Archivos de zootecnia 63(244): 611-621

Qurniawan. A. 2016. Kualitas Daging dan Performa Ayam Broiler Di Kandang Terbuka Pada Ketinggian Tempat Yang Berbeda Di Kabupaten Takalar Sulawesi Selatan tesis. Program Pascasarjana Institut Pertanian Bogor.

Rasyaf, M.2007. Beternak Ayam Pedaging. Penebar Swadaya. Jakarta.

Santoso, U. 2002. Pengaruh tipe kandang dan pembatasan pakan di awal pertumbuhan terhadap performans dan penimbunan lemak pada ayam pedaging unisexed. JITV. 7(2): 8489.

Sturky, P.D. and P. Griminger. 1976. Blood: Physical characteristics formedelements, hemoglobin and coagulation. Avian phisiology 3th ed spinger verlag New York Heinderberg, Berlin.

Tillman, A.D., H. Hartadi, S. Reksohadiprojo, S. Prawirokusumo dan S. Lebdosoekojo. 1991. Ilmu Makanan Ternak Dasar. Cetakan ke-
5. Gadjah Mada University Press. Yogyakarta

Tolkamp, B.J., V. Sandilands and I. Kyriajakis. 2005. Effects of qualitative feed restriction during reaning on the performance of broiler breeders during reaning and lay. Poultry Sci. 84:1286-1293

Wahju, J. 1992, Ilmu Nutrisi Unggas. Penerbit Gadjah Mada University Pres Yogyakarta.

Utami, D. P. 2011. Pembatasan ransum berpengaruh terhadap pertambahan bobot badan ayam broiler pada periode pertumbuhan. Mediargo 7(1):59-67 